Research Article

\title{
Assessment of Customers' Relationship Management Practices on Customer Retention and Loyalty of Oromia Credit and Saving Share Company: Bule Hora City Branch
}

\author{
Teshita Uke Chikako ${ }^{1}{ }^{1}$ and Gemedi Tesfaye Hamu ${ }^{2}$ \\ ${ }^{1}$ Wondo Genet College of Forestry and Natural Resource, Hawassa University, Hawassa, Ethiopia \\ ${ }^{2}$ Sawla College of Commerce and Business Administration, Arba Minch University, Sawla, Ethiopia \\ Correspondence should be addressed to Teshita Uke Chikako; tasheman09@gmail.com
}

Received 30 January 2021; Revised 27 May 2021; Accepted 14 June 2021; Published 24 June 2021

Academic Editor: Yi-Kuei Lin

Copyright (c) 2021 Teshita Uke Chikako and Gemedi Tesfaye Hamu. This is an open access article distributed under the Creative Commons Attribution License, which permits unrestricted use, distribution, and reproduction in any medium, provided the original work is properly cited.

\begin{abstract}
The main objective of this study was to assess customers' relationship management practices of Oromia Credit and Saving Share Company, Bule Hora city branch in Bule Hora, Ethiopia. Customer relationship management (CRM) as a strategy has gained tremendous interest among researchers and practitioners in recent times. Thus, this study tried to assess the status and ways CRM has been put in for practice by Oromia Credit and Saving Share Company (OCSSCO). In addition, this study considers different CRM dimensions such as empathy, bonding and satisfaction, and responsiveness. To achieve the objective of the study, primary data were collected through a questionnaire from a sample of 246 Oromia Credit and Saving Share Company customers of Bule Hora city branch, Bule Hora, Ethiopia, by using simple random sampling technique. The data collected through the questionnaire were analyzed using descriptive statistical analysis method and inferential statistics by using SPSS version 20 as a tool of data analysis. The study clearly revealed that the four CRM dimensions are strongly related. Thus, from the perspective of customers as well as management bodies of the Oromia Credit and Saving Share Company, CRM has a significant influence on customer retention and loyalty of the organization. Generally speaking, microfinance institutions are in need of doing a lot of CRM-based customer-focused practices.
\end{abstract}

\section{Introduction}

1.1. Background of the Study. A microfinance institution is a financial institution that provides loan to the poor business owner who in most cases has no access to financial institutions like bank, especially in developing countries. During the last three decades, microfinance has captured the attention of the academics and policy makers. This is among other things due to the success of the industry [1]

In a modern world of microfinance, the customer is the center of every single activity of the microfinance institution (MFI). The customers expect to have instant personalized and private services at the counters as well as getting the detailed, delight service satisfaction and special products. This was not easily attained in the previous banking era; however, the microfinance world has well grown in terms of innovation, creativity, and technology. Customer relationship management (CRM) is a strategy used to learn more about customers' needs and behaviors in order to develop stronger bond relationships with them. Overall good response for the customer is the heart of business success. It has been a core concept which has attracted all facets of business. It has relevant and demanding applications in service marketing. Financial services have also not been an exception to this phenomenon [2].

Thus, in enhancing MFIs, it was needed to understand the customers and their needs, preferences, and behaviors, and the microfinance employees needed to maintain strong customer relationship. Most of the organizations can maintain their CRM through the segregation of high value current customers, fulfilments of the customer's grievances, and special attention to most valuable customers, and redress 
of grievances can accelerate the periodic evaluation of customer needs that organize the permanent customer. When properly harnessed, microfinance offers a variety of benefits to the African people. Foremost, microfinance initiatives can effectively address material poverty, the physical deprivation of goods, services, and the income to attain them. When properly guided, the material benefits of micro financing can extend beyond the household into the community. At the personal level, microfinance can effectively address issues associated with nonmaterial poverty, which includes social and psychological effects that prevent people from realizing their potential. The economic performance of Sub-Saharan Africa (SSA) and other regions over the past three decades has been closely associated with their savings and investments. In fact, Africa's relatively slow economic growth has been linked to its poor capital accumulation [3].

Ethiopian microfinance sector is characterized by its rapid growth, an aggressive drive to achieve scale, a broad geographic coverage, a dominance of government-backed MFIs, an emphasis on rural households, the promotion of both credit and savings products, a strong focus on sustainability, and the fact that the sector is Ethiopian owned and driven [4].

1.2. Statement of the Problem. Customer relationship management is a management approach that enables organizations to identify, attract, and increase retention of profitable customers through improved bond customer relationship management [5].

However, successful customer relationship management focuses on understanding the needs and desires of the customers and is achieved by placing these needs at the heart of the business by integrating them with the organization's strategy, people, technology, and business processes [6]. Ethiopia's microfinance sector is showing high growth trend from time to time, but there is low customer relationship management, and this makes the customer dissatisfied with the organization unless appropriate measures are taken as early as possible. So, the issue is how we can create and let the sector realize the very bond and empathic relationship with customer and inclusive development. Many studies have depicted that Ethiopian microfinance institutions are faced with numerous problems and challenges, such as low outreach, fund shortage, limited product diversification, limited research and innovation, and weak internal control system and MIS [7, 8]. However, this paper focuses on the status of bonding, responsiveness, empathy, and satisfaction of the customer towards the organization, lacking these may lead to loosing loyal customers, and providing solutions for these problems is unlikely to deliver long-lasting relief from the undesired effect. Thus, the question is, what are the root causes of all these problems?

1.3. Research Questions. The researchers intended to address the following questions:

(1) To what extent were the practices of empathy being implemented on customer retention and loyalty in the OCSSCO, Bule Hora city branch?
(2) How does OCSSCO Bule Hora perceive the practices of bonding with customer retention and loyalty?

(3) What challenges are faced by the OCSSCO, Bule Hora city branch, regarding responsiveness on customer retention and loyalty?

(4) To what extent did OCSSCO provide quality service to satisfy, retain, and make the customer loyal to the organization?

\subsection{Objective of the Study}

1.4.1. General Objective of the Study. The main objective of the study was to assess customer relationship management practices of Oromia Credit Saving and Share Company, Bule Hora city branch, on customers retention and loyalty.

\subsubsection{Specific Objectives of the Study.}

(i) To assess the practices of empathy implemented in OCSSCO, Bule Hora city branch, on customer retention and loyalty

(ii) To assess perception on bond customer relationship management practices of OCSSCO, Bule Hora city branch, on retention and loyalty

(iii) To assess the challenges of CRM applications regarding responsiveness on customers retention and loyalty

(iv) To assess the level of satisfaction on customer retention and loyalty within OCSSCO, Bule Hora city branch

1.5. Conceptual Framework. The author of [9] disclosed that satisfaction, empathy, bonding, and responsiveness are the dimensions of customer relationship management. Das et al.[10] define CRM and RM are focused on individual buyerseller relationships, which accept that these relationships are longitudinal in nature that both parties benefit in the process. These researchers divide different mechanisms of customer relationship management into internal and external programs. According to them, internal programs emphasize on organizational structure, culture, and knowledge management, while external programs include interactive activities with customers (for example, information exchange with the customer or involving him/her). Thus, based on this, the present paper has been focused on external programs of customer relationship management. This is, therefore, although CRM practices are measured under different dimensions but for this study the relevant dimensions are satisfaction, empathy, bonding, and responsiveness.

\subsection{Relationship between Empathy and Customer Retention.} The researchers assessed how customers perceived the selected microfinance and were empathic towards them. Empathy (including access, communication, and understanding the customer) was caring and individualizing 
attention that the firm provides to its customers [11]. If the customers feel well treated and assured of good relationship, they have remained loyal. Empathy, a key component of emotional intelligence, is essential for harmonious and productive relationships in the workplace as much as in personal life. Empathy is the dimension of a business relationship that enables each of two parties to see a situation from the other's per. It is defined as seeking to understand somebody else desires and goals. It involves the ability of individual parties to view the situation from the other party's perspective in a truly cognitive sense [12]. Previous studies in [11-13] indicated that empathy is a necessary condition to foster a positive relationship between two parties and it has significant effect on customer retention. These findings prompted the following hypothesis:

$\mathrm{H}_{1}$ : an empathy practice has positive relationship with customer retention.

1.7. Relationship between Bonding and Customer Retention. Bonding is defined as the dimension of a business relationship that results in two parties (the customer and the supplier) acting in a unified manner towards a desired goal [14]. Thus, bonding helps in the development of key relationships with customers. In addition to the above fact, it is also accepted that bonding would strengthen relationships and loyalty. Bonding is an essential element to establish long-lasting relationship with customers. In the dyadic relationship of a buyer and a seller, bonding can be described as a dynamic process that is progressive over time. Bonds have served effectively to control social and business behavior in society [15]. A significant effect of bonding on customer retention was also shown. Similarly, the study in [16] also found the same relationship of bonding on customer retention. Based on these empirical findings, we hypothesized the following:

$\mathrm{H}_{2}$ : there is a significantly positive relationship between bonding and customer retention.

1.8. Relationship between Responsiveness and Customer Retention. Responsiveness has to do with the degree with which MFIs were able to respond to the needs and wants of customers. For a firm to be responsive, it must gain deeper understanding and profiling of customer behavior, real-time customer information and loyalty, and management at Point of Service. However, the study in [17] described that responsiveness is the degree to which customers perceive service providers' readiness to assist them promptly and examined the effect of responsiveness on customer retention in a company engaged in cellular service. The results therein showed that customer trust affects customer retention. Significant links between customer responsiveness and customer retention were also found in $[18,19]$. Based on the results presented, the following hypothesis was tested in this study:

$\mathrm{H}_{3}$ : responsiveness has a significant effect on customer's retention.
1.9. Relationship between Satisfaction and Customer Retention. Customer satisfaction is a measure of how products and services supplied by a company meet or surpass customers' expectation [20]. It was proposed that when perceived service quality is high, then it will lead to increase in customer satisfaction. Several researchers found that customer satisfaction significantly influences customer retention in various sectors, namely, insurance company [21], life insurance services [22], and banking [19,23] and also argued that customer satisfaction will improve customer retention. This has resulted in the following hypothesis:

$\mathrm{H}_{4}$ : customer satisfaction has a significant effect on customer retention.

Generally, based on the empirical studies reviewed above, it is hypothesized that customer-empathy, bonding, and responsiveness influence customer retention through customer satisfaction. Figure 1shows how the series of independent variables are related to the dependent variable. The overall assumption was that the degree of customer retention was dependent on degree of the practice by Oromia Credit and Saving Share Company to satisfy customers. A satisfied customer will enter into a long-term relationship with sellers. A long-term buyer-seller relationship is very important to create longer term customer retention. The research findings revealed that the overall service quality provided by the Oromia Credit and Saving Share Company of Bule Hora city had a direct relationship with customer retention and loyalty. However, despite improving services, still the organizations develop the best strategies which can be applied to retain customers by using these four customer relation dimensions (empathy, bonding, responsiveness, and satisfaction) which shows maintaining service quality alone is not a sufficient factor. In addition, the gap still exists since the researchers did not observe other constructs such as trust and commitment which actually may have profound effects on customer retention.

\section{Methodology}

2.1. Sources of Data and Collection Instruments. The data required for this study would be gathered from both primary and secondary sources. Primary data would be collected through questionnaires and interview. A closedended questionnaire was developed to conduct the research in the study area, and the questionnaire developed in this study consisted of two parts. The first part was regarding demographic characteristics of the respondents; the second part consists of the perception of customers regarding OCSSCO, Bule Hora city branch. The researchers developed close-ended questions for its contribution to know the respondents perception and helps the respondents to choose one option from the given scale alternative (strongly disagree, disagree, Neutral, agree, and strongly agree) which aligns with their views. Under second-part questions regarding the perception of customers' variables (empathy, bonding, responsiveness, satisfaction, and customer relationship management (retention and loyalty)), each of them has eight questions 


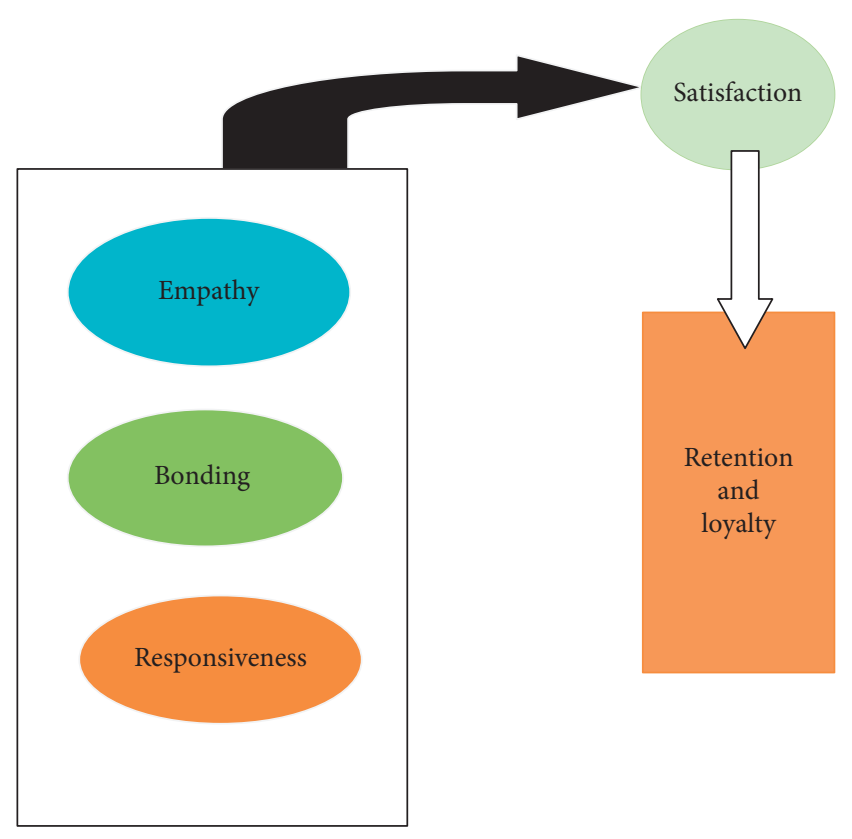

FIgURE 1: Conceptual frame work.

(item number) and these questions can be measured by five-point Likert scales ranging from strongly disagree to strongly agree. Thus, the primary data of survey would be collected from the customers of the organization. This primary source of data aids in obtaining important information from the target population and helps the researchers to find out detailed information regarding the topic to answer the research question and objectives. The secondary data would be collected from annual reports of the organization, marketing related books, manuals, journals and articles, official documents, reports, and newspapers. Besides, knowledge-based technologies such as the Internet were reviewed to triangulate the study. The secondary source of data enables the researcher to collect information needed easily within short period of time, less cost, and less effort.

\subsection{Sampling Techniques and Sample Size Determination.} For the purpose of this study, the researchers used simple random sampling techniques, because the target population was homogenous and they provide equal chance for the sample respondents. From the total population of 730 customers of Bule Hora city branch microfinance, a sample of 246 respondents were taken and the questionnaires were distributed to cover the formula in the study by Yamane (1967:886) to calculate sample sizes.

\subsection{Variable in the Study}

2.3.1. Dependent Variable. The values of a dependent variable are based on other variables; as other variable(s) changed, its value was changed. Therefore, the dependent variable is the customer relationship management (customers' retention and loyalty) that depends on the practice of the organization to retain the customers.
2.3.2. Independent Variables. The independent variables are the variables that are not based on other variable(s), or it is a variable that judges itself. The independent variables of this study were practice of the organization that includes bonding, empathy, responsiveness, and satisfaction to build long-term and strong relationship with customers.

2.4. Research Design. The study is of the descriptive type. A descriptive study attempts to describe or define a subject, undertaking within the organization and outside of the organization concerning customer relationship management practices of OCSSCO, Bule Hora city branch.

Zegeye [24] stated that the goal of descriptive research is to describe some aspect of a phenomenon, that is, the status of a given phenomenon. However, although some people dismiss descriptive research as "mere description," good description is fundamental to the research enterprise, and it has added immeasurably to our knowledge of the shape and nature of our society [25]. The researchers further argued that good description provokes the "why" questions of explanatory research. Therefore, according to the above fact, the researchers used descriptive, cross-sectional, and explanatory research design in order to describe CRM practices of Oromia Credit Saving and Share Company (OCSSCO) of Bule Hora branch. To do so, the researchers collected data through questionnaire and interview as well as focus group discussion in order to see the relationship between the variables.

For undertaking this study, the mixed research approach is preferred because it involves both qualitative and quantitative data which often relies on data in the form of descriptions and statistical summary or analysis. For primary data, structured questionnaire was used for quantitative data; interviews and focus group questions were used for qualitative data.

2.5. Data Organization and Analysis. Due to the nature of the study, the researchers employed both qualitative and quantitative approaches. Qualitative methods seek to provide answers to the interview as well as to present, analyze, and interpret the data that was gathered from questionnaires and other secondary sources. Concerning the quantitative approach, Statistical Package for Social Sciences (SPSS), version 20, was used for analyzing both descriptive and inferential statistics and analyzing the gathered information with the help of statistical tools like correlation, percentage, and multiple linear regression in the analysis of data and presentation of findings.

2.6. Reliability Test. The reliability of a measure is an indication of the stability and consistency with which the instrument measures the concept and helps to assess the "goodness" of a matter. The Cronbach alpha coefficient is an indicator of internal consistency of the scale [26]. The researchers cross-checked the reliability of the data in the concept of the closer Cronbach's alpha value to 1.0, the higher internal consistency reliability (Cronbach, 1946, cited 
in [27]). Accordingly, the reliability test in this study, which is based on Cronbach, measures that the reliability less than 0.6 is considered poor; reliability in the range of 0.7 is considered as acceptable, and the reliability of more than 0.8 is considered as good. Previously, distribution of the questionnaire to respondents' pilot test was employed to check consistency.

As conducted in [27], 10\% of the sample is sufficient to test the reliability of the measure. Accordingly, this study was tested by $10 \%$ of sample respondents of the study by using simple random sampling for the purpose of eliminating the ambiguity of words; and also it helps to check the clarity of measures to the respondents and at what extent they understood the questionnaire. During the pilot test, the results of each dimension of variables, Cronbach's alpha value, were $0.712-0.861$ as can be seen in Table 1 . The outputs of the reliability analysis of all dimensions in the study were 0.924 and are presented in Table 1 .

2.7. Measurement Scale. The researchers used the Likert scale from $1-5$, which is appropriate for the responder to give opinion, which is strongly disagree, disagree, neutral agree, and strongly agree, respectively, and is simple for the researchers to analyze and code closed- and open-ended questions, followed by rating scale during conducting the research.

\section{Results}

3.1. Demographic Characteristics of Respondents. This aspect of the analysis dealt with the basic data of the respondents to whom the questionnaires were sent. The basic data comprised the respondents' sex, age, educational level, and marital status. Table 2shows the details of the respondents' demographic data.

Table 2shows the demographic characteristics of respondents for OCSSCO, Bule Hora branch. Out of 246 respondents, $45.5 \%$ were males and $54.5 \%$ were females. The evidence from the above table showed that the age of majority of OCSSCO users was found to be 35-40 (26.8\%). Respondents with age groups between 18 and 23, between 24 and 29 , and between 30 and 34 years account for $15.0 \%$, $15.4 \%$, and $26.0 \%$, respectively. The remaining $16.3 \%$ and $0.4 \%$ are respondents in the age groups between 41 and 45 and between 46 and 50 years, respectively.

The result of Table 2regarding educational status of the respondent showed that $31.3 \%$ of the respondents were illiterate (cannot read and write), $20.3 \%$ of the respondents were between grades $1-8,24.0 \%$ of respondents were between grades $9-12,12.6 \%$ of respondents were diploma holders, and $11.8 \%$ of respondents were degree holder.

The above table also reveals that the majority of respondents were found to be married, with a percentage of $81.7 \%$, and the remaining $16.7 \%$ and $1.6 \%$ of the respondents were found to be unmarried and divorced, respectively.

With regard to length of membership with their OCSSCO, 35\% of sampled respondents have less than or equal to 3 years of OCSSCO membership, about $33.3 \%$ of respondents have between 4 and 6 years of OCSSCO memberships, about 23.2\% have between 6 and 9 years of OCSSCO memberships, and the remaining $8.5 \%$ of them sticked to OCSSCO for more than 9 years. Most sample respondents (65\%) stay with the OCSSCO for more than three years. Thus, the longer the customer stayed with the OCSSCO, the stronger the relationship he/she could develop. As a result, this may lead both the OCSSCO and customer to trust each other, and the customers will be willing to recommend their OCSSCO to friends, family members, and others and generate positive word of mouth. This entails that the OCSSCO is effective and in a right track on retaining existing customers rather than attracting new ones.

3.2. Customer Relationship Management Variables. The researchers used four variables (empathy, bonding, responsiveness, and satisfaction). Multiple linear regression analysis and correlation has been also conducted to confirm the significance of empathy, bonding, responsiveness, satisfaction, and CRM variables for OCSSCO. To confirm their significance, all variables were measured by different response results from strongly disagree to strongly agree.

3.3. Correlation. Correlation measures the strength of the linear relationship between two variables. Thus, Pearson's correlation is used to identify whether there are linear relationships between the variables and to describe the strength and the direction of the linear relationship between two variables [28]. According to [29], the level of relationship as measured by Pearson's coefficient falls between -1.0 and +1.0 , which indicates the strength and direction of relationship between the two variables. The interpretation of the result is as follows: a correlation result between 0 and 1 implies positive linear relationship, 0 (zero) implies no linear relationship, 1 implies perfect positive (direct) linear relationship, -1 implies perfect negative (inverse) linear relationship, and between -1 and 0 indicates the existence of negative linear relationship. Although it indicates the existence of a positive or negative linear relationship, the strength of such a linear relationship is not high when the results fall below \pm 0.61 [30]. It is also supported by [29] and the rules of thumb suggest that "moderate" ends at \pm 0.60 and "strong" starts at \pm 0.61 .

As is clearly shown in Table 3, there exists strong (since all the correlation coefficients are greater than the agreed standard, 0.61) and positive linear relationship between different CRM dimensions (empathy, bonding, satisfaction, and responsiveness variables) and it is also found to be significant at $95 \%$ confidence interval.

There was a positive relationship between empathy and customer retention. The main underlying assumption is that the higher the empathy towards the customers, the higher the customer retention using the microfinance services, depending on the perception of the respondent microfinance institution committed to have emphatic relationship with the customers to retain the profitable customers. 
TABLE 1: Reliability statistics.

\begin{tabular}{lcc}
\hline Variables & No. of items & Alpha value \\
\hline Customer relationship management (retention and loyalty) & 8 & 0.712 \\
Satisfaction & 8 & 0.753 \\
Responsiveness & 8 & 0.843 \\
Bonding & 8 & 0.854 \\
Empathy & 8 & 0.861 \\
Total variable reliability & 5 & 0.924 \\
\hline
\end{tabular}

TABle 2: Demographic characteristics of the respondents.

\begin{tabular}{|c|c|c|c|c|}
\hline Parameters & & Frequency & Percentage & Cumulative (\%) \\
\hline \multirow{3}{*}{ Gender } & Female & 134 & 54.5 & 54.5 \\
\hline & Male & 112 & 45.5 & 100.0 \\
\hline & Total & 246 & 100.0 & \\
\hline \multirow{4}{*}{ Marital status } & Married & 201 & 81.7 & 81.7 \\
\hline & Unmarried & 41 & 16.7 & 98.4 \\
\hline & Divorced & 4 & 1.6 & 100.0 \\
\hline & Total & 246 & 100.0 & \\
\hline \multirow{7}{*}{ Age } & $18-23$ & 37 & 15.0 & 15.0 \\
\hline & $24-29$ & 38 & 15.4 & 30.5 \\
\hline & $30-34$ & 64 & 26.0 & 56.5 \\
\hline & $35-40$ & 66 & 26.8 & 83.3 \\
\hline & $41-45$ & 40 & 16.3 & 99.6 \\
\hline & $46-50$ & 1 & 0.4 & 100.0 \\
\hline & Total & 246 & 100.0 & \\
\hline \multirow{6}{*}{ Educational level } & Illiterate & 77 & 31.3 & 31.3 \\
\hline & Grades 1-8 & 50 & 20.3 & 51.6 \\
\hline & Grades 9-12 & 59 & 24.0 & 75.6 \\
\hline & Diploma & 31 & 12.6 & 88.2 \\
\hline & Degree and above & 29 & 11.8 & 100 \\
\hline & Total & 246 & 100.0 & \\
\hline \multirow{5}{*}{ Membership year } & $1-3$ & 86 & 35.0 & 35.0 \\
\hline & $4-6$ & 82 & 33.3 & 68.3 \\
\hline & $7-9$ & 57 & 23.2 & 91.5 \\
\hline & $>9$ & 21 & 8.5 & 100.0 \\
\hline & Total & 246 & 100.0 & \\
\hline
\end{tabular}

TABLE 3: Correlation analysis result.

\begin{tabular}{|c|c|c|c|c|c|c|}
\hline & & Empathy & Bonding & Responsiveness & Satisfaction & Customer retention \\
\hline \multirow{2}{*}{ Empathy } & Pearson's correlation & 1 & $0.649^{* *}$ & $0.486^{* *}$ & $0.521^{* *}$ & $0.541^{* *}$ \\
\hline & Sig. (2-tailed) & & 0.000 & 0.000 & 0.000 & 0.000 \\
\hline \multirow{2}{*}{ Bonding } & Pearson's correlation & $0.649^{* *}$ & 1 & $0.511^{* *}$ & $0.485^{* *}$ & $0.623^{* *}$ \\
\hline & Sig. (2-tailed) & 0.000 & & 0.000 & 0.000 & 0.000 \\
\hline \multirow{2}{*}{ Responsiveness } & Pearson's correlation & $0.86^{* *}$ & $0.511^{* *}$ & 1 & $0.445^{* *}$ & $0.638^{* *}$ \\
\hline & Sig. (2-tailed) & 0.000 & 0.000 & & 0.000 & 0.000 \\
\hline \multirow{2}{*}{ Satisfaction } & Pearson's correlation & $0.521^{* *}$ & $0.485^{* *}$ & $0.445^{* *}$ & 1 & $0.747^{* *}$ \\
\hline & Sig. (2-tailed) & 0.000 & 0.000 & 0.000 & & 0.000 \\
\hline \multirow{2}{*}{ Customer retention } & Pearson's correlation & $0.541^{* *}$ & $0.623^{* *}$ & $0.638^{* *}$ & $0.747^{* *}$ & 1 \\
\hline & Sig. (2-tailed) & 0.000 & 0.000 & 0.000 & 0.000 & \\
\hline
\end{tabular}

${ }^{* *}$ Significant at 0.001 and ${ }^{*}$ Significant at 0.05

There was a strong significantly positive relationship between bonding and customer retention. This indicates the leaner bond relationship assumed to build long-term relationship, and it shows that as bonding increases, the customer retention also increases. The other correlation result in Table 3also shows that there was a strong positive 
relationship between responsiveness and customer retention. The assumption is that providing prompt and timely response is likely to have a good relationship with OCSSCO. Responsiveness is a vital component for building a successful long-term relationship, and [31] stated that relationships are built on the foundation of mutual benefit. There was a strong positive relationship between customers' satisfaction and their retention. The assumption is that building a good relationship with the customer means retaining that customer. Customer satisfaction has been and still is regarded as a fundamental determinant of long-term consumer behavior. The more satisfied customers are, the greater their retention is.

3.4. Multiple Linear Regression Analysis. Regression analysis is the inferential statistics model used to know by how much the explanatory variable explains the response variable [32]; and it helps to understand by how much each explanatory variable explains the response variable. Accordingly, in this study, the regression analysis of predictor and customer relationship management (customers' retention and loyalty) was conducted, and the results of the regression analysis were presented here. Because the study contained more than two explanatory variables, the researchers used multiple linear regressions in the study.

As depicted in Table 4, the model summary of the analysis shows that the value of Adjusted $R$ square is 0.614, which means that $61.4 \%$ of variation in the dependent variable (customer retention) is being explained by independent variable (empathy, bonding, responsiveness, and satisfaction). In this regard, the remaining $38.6 \%$ of the customer retention is influenced by other factors such as selection and recruitment, promotion, organizational culture, organizational climate, organizational resource, and the like. Thus, it is indicated that the relationship between the predictor variables and the response variable (customer retention) is very high $(r=0.796)$. So we can state that all the explanatory variables can significantly influence customer retention.

The regression result of ANOVA in Table 5of all explanatory variable with customer retention shows statistical significance because the $F$-test value is 19.688 , which is significant due to $p$ value $=0.000$ which is less than 0.05 . This indicates that the overall model is significant.

In Table 6, all predictors' variables of beta value or standardized coefficients in the analysis were positive. Thus, the positive value of independent variables on the dependent variable indicates that there is a direct relationship between employee's customer retention and independent variables of empathy, bonding, responsiveness, and satisfaction. According to Table 6, all explanatory variables are statistically significant and the regression model is valid. Further, it is possible to interpret the beta value depicted in Table 6, regarding its effects on customer retention. The following is clear from the analysis:

(i) Empathy $\left(\beta_{1}\right)=0.203$ or $20.3 \%$, which indicates that one-percent increase in empathy of employees increases $20.3 \%$ of customer retention level if the
TABle 4: Model summary.

\begin{tabular}{lcccc}
\hline Model & $R$ & $R$ square & $\begin{array}{c}\text { Adjusted } \\
R \text { square }\end{array}$ & $\begin{array}{c}\text { Std. error of the } \\
\text { estimate }\end{array}$ \\
\hline 1 & 0.796 & 0.634 & 0.614 & 0.652 \\
\hline
\end{tabular}

TABLE 5: ANOVA results of the regression analysis.

\begin{tabular}{ccccccc}
\hline & Model & Sum of squares & df & Mean square & $F$ & Sig. \\
\hline & Regression & 33.569 & 4 & 8.392 & 19.688 & 0.000 \\
1 & Residual & 102.729 & 241 & 0.426 & & \\
& Total & 136.298 & 245 & & & \\
\hline
\end{tabular}

TABLE 6: Results of the regression analysis.

\begin{tabular}{lcccccc}
\hline Variables & Beta & $\begin{array}{c}\text { Std. } \\
\text { error }\end{array}$ & $t$ & Sig. & Tolerance & VIF \\
\hline (Constant) & 1.514 & 0.275 & 5.506 & 0.000 & & \\
Empathy & 0.203 & 0.076 & 2.653 & 0.009 & 0.541 & 1.848 \\
Bonding & 0.222 & 0.077 & 2.896 & 0.004 & 0.526 & 1.899 \\
Responsiveness & 0.149 & 0.070 & 2.115 & 0.035 & 0.696 & 1.437 \\
Satisfaction & 0.047 & 0.045 & 1.035 & 0.030 & 0.943 & 1.061 \\
\hline
\end{tabular}

other variables are kept controlled in the study; and also it implies that the change of one standard deviation in the empathy resulted in a change of $20.3 \%$ standard deviation in the customer retention. Since the value of $\beta_{1}$ is positive, it indicates that there is a significant direct (positive) relationship between empathy and retention; and also the result shows that there is a significant impact of empathy on customer retention. This implies that the higher the beta value, the greater the impact of the predictor variable on the response variable. This result is similar to those of the studies done by [11-13].

(ii) Bonding $\left(\beta_{2}\right)=0.222$ or $22.2 \%$, which implies that one-percent increase in bonding of employees increases $22.2 \%$ of customer retention level if remaining variables remained controlled in the study. Here also the positive value of $\beta_{2}$ shows the direct relation between bonding and customer retention and it has a statistically significant effect on customer retention. The result shows that $22.2 \%$ of effect on customer retention in the study area comes from bonding. This result maintains what is stated with studies done by $[15,16,30]$.

(iii) Responsiveness $\left(\beta_{3}\right)=0.149$ or $14.9 \%$, which indicates that one-percent increase in responsiveness of employees increases $14.9 \%$ of customer retention when the other variables remained controlled. The output of the study in Table 5shows that the change of one standard deviation in the responsiveness resulted in change of $14.9 \%$ standard deviation in the customer retention. Therefore, from the result, we conclude that there is a statistically significant effect of responsiveness on customer retention. This finding is consistent with the previous studies done by [17-19]. 
(iv) Satisfaction $\left(\beta_{4}\right)=0.047$ or $4.7 \%$, which shows that one-percent increase in satisfaction of customers increases $4.7 \%$ of customer retention level because of its positive beta value if the remaining variables remained controlled. This shows that there is a positive relationship between satisfaction and customer retention and satisfaction has clear significant effect on customer retention. This result maintains what is stated with studies done in [21-23, 30].

\section{Conclusion}

The study emphasizes on the existence of a relationship between the OCSSCO, Bule Hora branch, and its customers measured by customer relationship management practices.

Empathy involves caring and individual attention, while the company provides its services for the customers. Customers become loyal to their office when they get respect and individual attention which is one of the main parts of quality service. In microfinance, empathy and providing microfinance quality services are the basis of sound CRM. From the results obtained, customers of the employees of microfinance openly speak their feeling during service provision. However, it is difficult to arrive at such conclusion and generalize that the employees of the institution show empathic relationship during the service provision well, since there were some respondents who disagreed and remained neutral.

The aim of CRM is also to establish, maintain, and enhance long-term customer relationships with customers. So, doing what is showing individual attention and solving their problem is the fundamental issue for the customer. Although the majority of the respondents perceived that there was an empathic relationship between the Oromia Credit and Saving Share Company (OCSSCO), Bule Hora city branch, and its customers, there is a slight difference among them. It is common that as empathy declines, customers are unwilling to conduct business transaction. Particularly to the microfinance institutions, empathy leads to constructing long-term relationship with their customers. Though there are customers who have doubt about empathy of the institution specially on the advanced technology, majority of them perceived that the Oromia credit and saving share company was emphatic toward their customer.

Regarding bond relationship between the MFIs and their customers, the majority of the respondents of microfinance perceived that their institution remained in touch constantly with microfinance institution. Similarly, the OCSSCO, Bule Hora city branch, tries very hard to establish long-term relationship with customers. Significant numbers of customers were agreeing on this statement. However, some respondents perceived that the institutions provided membership benefit for loyal customers and integrated new system to update the service. Successful bond CRM focuses also on understanding the needs and desires of the customers and remaining in touch constantly to achieve long-term relationship by placing these needs at the heart of the business by integrating them with the organization's strategy, people, and technology and business process. In this regard, the OCSSCO and customers were found to have bond relation for their mutual benefits.

It is also known that one of the CRM goals is to create and maintain long-lasting relationships between the OCSSCO and its customers. One measurement for CRM is responsiveness. Responsiveness is a key component for timely replay of customer requirement to provide quality service and productive relationships in the work place. Thus, responsiveness can be viewed as the capability of understanding needs and wants of customers in a relational situation. In line with this, the employees of OCSSCO are ready to respond towards their customers and show willingness to the customer-based service and provide genuine and detailed information regarding the service microfinance available. In contrary, some customers have a little doubt on calling them back when something wrong happens during the transaction and learning customer-specific requirement. As a result, they face challenges for application of CRM to sustain the relationship.

Finally, the purpose of customer retention is to keep a high proportion of valuable customers through reducing customer dissatisfaction and increasing satisfaction. Concerning this, the microfinance institution tries its best to understand the feeling of the customer and handling his/her complaint timely, plus welcoming them with bright face when they come to the office to take the services. Not only these, the majority of the respondents were in need to process pass thought to get different simple and fast service. From the descriptive statistics results of this study, there exists a relationship between CRM and customer retention. The results clearly revealed that the four CRM dimensions are very close. This shows us that CRM has a significant influence on customer relation or retention from customers' view. Although a further detailed study is needed, generally, the results indicate that customer relationship management is important for customer retention which is essential for the success of Oromia Credit and Saving Share Company.

\section{Abbreviations \\ CRM: $\quad$ Customer relationship management \\ RM: $\quad$ Relationship marketing \\ SPSS: $\quad$ Statistical Package for the Social Sciences \\ OCSSCO: Oromia Credit and Saving Share Company \\ MFI: Microfinance institutions \\ ATM: $\quad$ Automated Teller Machine.}

\section{Data Availability}

The data used to support the findings of this study are available from the corresponding author upon request.

\section{Conflicts of Interest}

The authors declare that they have no conflicts of interest.

\section{Acknowledgments}

The authors acknowledge Oromia Credit and Saving Share Company (OCSSCO), Bule Hora city branch, and thank Solomon Amare for his advice during this work. 


\section{References}

[1] E. Assefa, N. Hermes, and A. Meesters, "Competition and the performance of microfinance institutions," Applied Financial Economics, vol. 23, no. 9, pp. 767-782, 2013.

[2] R. Agarwal, Microfinance Institutions Study with Reference to Customer Relation Management, School of Management Studies Punjabi University, Patiala, Punjab, India, 2009.

[3] D. I. Cahill, "Relationship marketing? but all i really wanted was a one-night stand. marketing news," Journal of Marketing Management, 1996.

[4] D. Ebisa, N. Netachew, and F. Mitiku, Filling the Branch Microfinance, Department of Managment Hawassa University, Hawassa, Ethiopia, 2013.

[5] E. Blery and M. Michalakopoulos, "Customer relationship management: a case study of a Greek bank," Journal of Financial Services Marketing, vol. 11, pp. 116-124, 2006.

[6] F. A. Buttle, The Customer Relationship Management Value Chain, Marketing Business, Department of Managment Macquarie University, Sydney, Australia, 2001.

[7] A. Wolday, Review of Micro Finance Industry in Ethiopia: Regulatory Frameworks and Performance, AEMFI, Addis Ababa, Ethiopia, 2000.

[8] Y. Kassa, "Regulation \& supervision of microfinance business in Ethiopia achievements, challenges \& prospects," in Proceedings of the International Conference on Microfinance Regulations, Ethiopia, March 2010.

[9] P. Kotler, "Building customer satisfaction, value, and retention," Jounal of Marketing Management, 2006.

[10] K. Das, J. Parmar, and V. K. Sadanand, "Customer relationship management (CRM) best practices and customer loyalty a study of Indian retail banking sector," European Journal of Social Sciences, vol. 11, no. 1, pp. 61-85, 2009.

[11] S. Knox, S. Maklan, A. Payne, J. Peppard, and L. Ryals, Customer Relationship Management: Perspectives from the Marketplace, Butterworth-Heinemann, Burlington, MA, USA, 2003.

[12] K.-k. Hwang, "Face and favor: the Chinese power game," American Journal of Sociology, vol. 92, no. 4, pp. 944-974, 1987.

[13] C. H. Ferguson, "Computers and the coming of the US keiretsu," Harvard Business Review, vol. 68, no. 4, pp. 55-70, 1990.

[14] M. Taleghani, S. Gilaninia, and S. J. Mousavian, "The role of relationship marketing in customer orientation process in the banking industry with focus on loyalty (case study: banking industry of Iran)," International Journal of Business and Social Science, 2011.

[15] A. Samudro, U. Sumarwan, M. Simanjuntak, and E. Yusuf, "How commitment, satisfaction, and cost fluctuations influence customer loyalty," GATR Journal of Management and Marketing Review, vol. 4, no. 2, pp. 115-125, 2019.

[16] P. Mbango, "The role of perceived value in promoting customer satisfaction: antecedents and consequences," Cogent Social Sciences, vol. 5, no. 1, Article ID 1684229, 2019.

[17] R. Tamilarasan, "Customer relationship management in microfinance services, India," Advances in Management, vol. 4, no. $1,2011$.

[18] H. Setiawan and A. J. Sayuti, "Effect of service quality, customer trust and corporate image on customer satisfaction and loyalty: an assessment of travel agencies customer in South Sumatera Indonesia," Journal of Business and Management, 2017.

[19] L. Vithya, "The relationship between customer satisfaction and customer trust on customer loyalty," International
Journal of Academic Research in Business and Social Science, 2017.

[20] E. Ottero, "The new marketing: developing long-term interactive relationships," Long Range Micro Finance Planning, vol. 20, no. 4, 1999.

[21] Z. Daneshfar, A. Roshani, and H. Sabzali, "Evaluating customer retention and satisfaction and the reason of losing customers in the auto insurance (a case study)," in Proceedings of the 2016 International Conference on Industrial Engineering and Operations Management, Kuala Lumpur, Malaysia, September 2016.

[22] H. T. Nguyen, H. Nguyen, N. D. Nguyen, and A. C. Phan, "Determinants of customer satisfaction and loyalty in Vietnamese life-insurance setting," Sustainability, vol. 10, no. 4, p. 1151, 2018.

[23] A. Samudro, U. Sumarwan, M. Simanjuntak, and E. Z. Yusuf, "Assessing the effects of perceived quality and perceived value on customer satisfaction," Management Science Letters, 2020.

[24] A. Zegeye, A. Worku, D. Tefera, M. Getu, and Y. Sileshi, "Introduction to research methods," Graduate Studies and Research Office Addis Ababa University, 2009.

[25] T. Velnampy and S. Sivesan, "Impact of customer relationship marketing on customer value creation in mobile service providers-a Sri Lankan experience," Journal of Marketing and Business Management, vol. 1, no. 1, pp. 16-21, 2012.

[26] V. Oogarah-Hanuman, S. Pudaruth, V. Kumar, and V. Anandkumar, "A study of customer perception of CRM initiatives in the Indian financial sector," Research Journal of Social Science and Management, vol. 1, 2011.

[27] G. R. Adem, "Factors determining employees affective commitment in jinka general hospital south omo zone, jinka town," Masters thesis, Department of Managment, Arba Mich University, Arba minch, Ethiopia, 2017.

[28] A. T. Mohammad, The effects of marketing communications on Malaysia's consumer based brand equity and intention to visit among potential tourists from Gulf Countries: The Case of Jeddah and Dubai, PhD. thesis, Universiti Utara Malaysia, Changlun, Malaysia, 2011.

[29] A. Berndt, F. Herbst, and L. Roux, "Implementing a customer relationship management programme in an emerging market," Journal of Global Business and Technology, vol. 1, no. 2, pp. 81-89, 2005.

[30] A. Solomon, "Assessment of customers' relationship management practices on customers in selected private banks ( $a$ comparative study)," Masters thesis, Mekele University, Mekele, Ethiopia, 2014.

[31] R. Bose, "Customer relationship management: key components for IT success," Industrial Management \& Data System, vol. 102, no. 2, pp. 89-97, 2002.

[32] J. G. Belás, "Reasons for satisfaction and dissatisfaction of microfinance customers. Study from Slovakia and the Czech Republic," International Journal of Entrepreneurial Knowledge, vol. 2, no. 14, pp. 4-13, 2014. 